\title{
Total parenteral nutrition in very low birthweight infants: a controlled trial
}

\author{
V. Y. H. YU, B. JAMES, P. HENDRY, AND R. A. MACMAHON \\ Department of Paediatrics, Queen Victoria Medical Centre, Melbourne, Australia
}

SUMMARY 34 preterm infants with birthweights $<1200 \mathrm{~g}$ were randomly assigned to total parenteral nutrition (TPN) or oral (Milk) feeding regimens for the first 2 weeks after birth. Infants in the TPN group were started on a modified Vamin-based glucose amino-acid infusion and Intralipid. The daily amounts of carbohydrate, amino-acids, and fat infusions were increased. In the Milk group, infants were started on intermittent gavage feeding, supplemented with a glucose-electrolyte infusion as necessary. The overall mortality rate did not differ in the two groups. Four infants in the Milk group developed necrotising enterocolitis but none did in the TPN group. Despite mean daily energy intakes which were not greatly different, there were much higher mean daily intakes of carbohydrate and protein in the TPN group compared with the Milk group. Fat intake in the TPN group was lower than in the Milk group in the 1st week because of neonatal jaundice which contraindicated the use of Intralipid. There was no difference in the mean daily fat intake by the 2nd week. Although mean daily weight loss in the 1 st week and the maximum postnatal weight loss in the two groups were similar, infants in the TPN group had a greater mean daily weight gain in the 2nd week and took less time to regain and maintain birthweight. Metabolic complications were equally common in both groups and were reversible with early recognition. Limits of tolerance for water and most nutrients tended to be variable and the nutritional programme had to be adjusted for each baby. Nevertheless, we found that TPN, when properly managed, is an effective and safe procedure in very low birthweight infants.

Advances in neonatal intensive care have resulted in better survival of very low birthweight infants. Adequate nutrition in the preterm neonate is considered to be important for immediate survival (Heird et al., 1972b) and for subsequent normal growth and development (Dobbing, 1974). This need for nutritional support often leads to the overzealous early introduction and excessive increases in volume of milk feeding, with a resulting increased risk of aspiration pneumonia (Wharton and Bower, 1965), cardiorespiratory disturbances (Yu, 1976), or necrotising enterocolitis (Yu et al., 1977).

Partial parenteral nutrition as a supplement to inadequate oral intake has been used successfully in low birthweight infants (Benda and Babson, 1971; Cashore et al., 1975), although comparative studies

\footnotetext{
Department of Paediatrics, Queen Victoria Medical Centre, Melbourne

V. Y. H. YU, director of neonatal intensive care

B. JAMES, professional officer

P. HENDRY, technical officer

R. A. MACMAHON, associate professor
}

of parenteral supplementation versus conventional feeding regimens showed similar morbidity and mortality (Bryan et al., 1973; Pildes et al., 1973; Brans et al., 1974; Abitbol et al., 1975). The feasibility of supplying complete requirements with total parenteral nutrition (TPN) via centrally placed catheters has been reported (Driscoll et al., 1972; Peden and Karpel, 1972; MacMahon et al., 1975; Hall and Rhodes, 1976; Meng et al., 1977). Although most reports claimed benefits with these techniques all but one (Gunn et al., 1978) lacked proper controls.

Because complications from intragastric milk feeding will contribute to the morbidity and mortality of very low birthweight infants, a study was accordingly designed to compare TPN with intragastric milk feeding supplemented as necessary with only a glucose-electrolyte solution.

\section{Patients}

Infants $<1200 \mathrm{~g}$ birthweights born, at the Queen Victoria Medical Centre or referred within 24 hours 
of birth, were considered for the study. After obtaining informed parental consent, the infants were assigned to a feeding regimen of either TPN or intragastric milk feeding (Milk). Assignment was by random card selection on alternate infants with the infant immediately following qualifying for the opposite study group. 40 infants $<1200 \mathrm{~g}$ birthweights, admitted to the neonatal intensive care unit during the 12-month period between July 1977 and June 1978, were consecutively enrolled in the study with all babies complying. Six infants died within 24 hours after birth before starting TPN or Milk feeding and were excluded. Therefore, 34 infants were studied.

\section{Methods}

Milk group. Intermittent gavage feeding via an orogastric tube was started as soon after birth as the clinical condition of the baby allowed. This was usually begun on day 1 and given every hour using fresh expressed breast milk from the infant's own mother, or a $67 \mathrm{kcal}(280 \mathrm{~kJ}) / 100 \mathrm{ml}$ milk formula (Similac, Ross Laboratories, N.S.W., Australia) if the former was unavailable.* The volume of milk was increased as rapidly as tolerated without abdominal distension, gastric retention, or regurgitation. An intake of $150 \mathrm{ml} / \mathrm{kg}$ per 24 hours was usually provided but this varied between 100 and $200 \mathrm{ml} / \mathrm{kg}$, depending on the clinical condition of the infant. An infusion of dextrose, water, and electrolytes was supplemented as necessary to maintain normal hydration and biochemical status. The infusate consisted of $5 \%$ dextrose and this was increased to a $10 \%$ solution as tolerated. As the oral intake increased, so was the infusion rate decreased. Daily oral multivitamin supplements were given from the 1st week. Any infant in the Milk group who remained nil-orally for more than 3 days after birth or in whom feeds had to be withheld for more than 24 hours subsequently during the 2 -week trial period was considered as a trial failure and withdrawn. The subsequent progress of such infants is excluded from the analysis of results. Trial failure infants and infants whose oral intake was $<100 \mathrm{kcal} / \mathrm{kg}$ on day 14 , on completion of the 2-week trial period, were offered parenteral nutrition supplements.

TPN group. A glucose amino-acid solution, based on Vamin N (Vitrum, Stockholm, Sweden) with added electrolytes, vitamins, and trace minerals was prepared by the pharmacy according to the programme

* Similac has a composition close to that of human breast milk (protein $1.5 \mathrm{~g} / 100 \mathrm{ml}$, fat $3.7 \mathrm{~g} / 100 \mathrm{ml}$, carbohydrate $7.0 \mathrm{~g} / 100 \mathrm{ml}$ ) prepared from nonfat cows' milk, vegetable oil, and added lactose. shown in Table 1. TPN was prescribed on admission to the study beginning with formula $1 \mathrm{~A}$. The glucose infusion rate was increased from 8 to $18 \mathrm{~g} / \mathrm{kg}$ per 24 hours in daily increments of $2 \mathrm{~g} / \mathrm{kg}$ by upgrading from formula $1 \mathrm{~A}$ to $3 \mathrm{~B}$ if hyperglycaemia (blood glucose $>11 \mathrm{mmol} / \mathrm{l} ;>198 \mathrm{mg} / 100$ $\mathrm{ml}$ ) or glycosuria (Clinitest $>0.5 \%$ ) was not encountered. The programme allowed for an increase in the daily amount of amino-acid infused from 1 to $3 \mathrm{~g} / \mathrm{kg}$ over 6 days. If there was glucose intolerance, the daily amount of glucose was adjusted, independent of the amino-acid intake. A soybean emulsion (Intralipid 20\%, Vitrum, Stockholm, Sweden) was started at a level of $1 \mathrm{~g} / \mathrm{kg}$ fat per 24 hours after recovery from neonatal jaundice (serum bilirubin $<150 \mu \mathrm{mol} / 1$ ( $<8.8 \mathrm{mg} / 100 \mathrm{ml})$ and falling). This amount was increased, in the absence of visible lipaemia, to a maximum of $3 \mathrm{~g} / \mathrm{kg}$ per 24 hours. If daily serum specimens showed more than a trace of lipaemia (equivalent to $2.8 \mathrm{mmol} / 1(250 \mathrm{mg} / 100 \mathrm{ml})$ triglyceride), lipid intake was reduced. The electrolyte content of the TPN solution was adjusted as shown by the biochemical status. As with infants in the Milk group, an intake of $150 \mathrm{ml} / \mathrm{kg}$ per 24 hours was generally provided, but this varied between 100 and $200 \mathrm{ml} / \mathrm{kg}$ depending on the clinical condition of the infant.

Infusion technique. TPN and supplemental glucose solutions (in the Milk group) were infused via the indwelling umbilical arterial catheter inserted in infants with respiratory distress or via peripheral veins when the former was not required. Catheter placement was in the descending aorta with the tip

Table 1 Composition of TPN solution; amount infused $(\mathrm{kg} / 24$ hours)

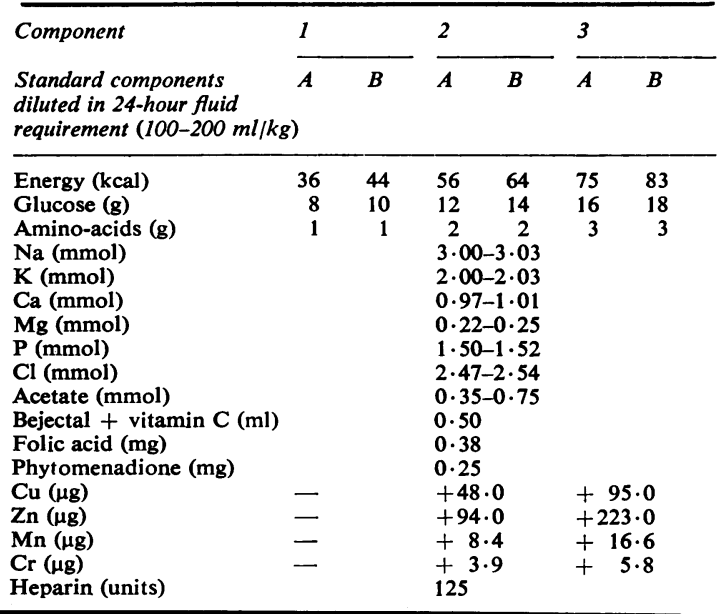


at the level of the 3rd lumbar vertebra. An $0.22 \mu \mathrm{m}$ Ivex 2 filter (Millipore, N.S.W., Australia) and an Ivac infusion pump (Watson-Victor, Victoria, Australia) were used for the glucose amino-acid infusion. Intralipid was infused continuously with a Harvard Syringe Pump (Stansen, Victoria, Australia) joining the glucose amino-acid mixture in a Y-connector distal to the filter and just proximal to the arterial catheter or intravenous needle. Infusates and administration sets were changed daily.

Monitoring. The infants were weighed daily to the nearest $10 \mathrm{~g}$. Urine was analysed at least twice daily for osmolality and glucose. Serum osmolality, glucose, sodium, potassium, calcium, magnesium, chloride, phosphate, and bilirubin (total and direct); haemoglobin and haematocrit; and acid-base status were measured daily in the 1st week and on alternate days in the 2 nd week of the study. The volume of blood required for these tests was $1.4 \mathrm{ml}$. The serum was also checked daily for visible lipaemia. Serum glutamic-oxalo-acetic transaminase, alkaline phosphatase, protein, urea, ammonia, lactate, transferrin, caeruloplasmin, and trace elements $(\mathrm{Fe}, \mathrm{Cu}$, $\mathrm{Zn}, \mathrm{Mn}, \mathrm{Cr}$ ) were measured on days 7 and 14 of the study. The volume of blood required for these tests was $1.7 \mathrm{ml}$. Urine collection for 24 to 72 hours was done during the period of a nitrogen balance test.

Statistical evaluation. Significance of differences between fluid and nutrient intakes and body weight changes in infants on the two feeding regimens was determined using the Mann-Whitney $U$ test.

\section{Results}

Clinical data and mortality. No significant difference in birthweights or gestational ages was noted between the 34 infants in the study and the 6 infants who died within 24 hours after birth (Table 2). Overall mortality for infants $<1200 \mathrm{~g}$ was $32 \cdot 5 \%$.

Table 2 Biographical data and survival rate of all infants $<1200 \mathrm{~g}$ during study period

\begin{tabular}{|c|c|c|c|}
\hline \multirow[t]{2}{*}{ Infants } & \multirow{2}{*}{$\begin{array}{l}\text { Birthweight } \\
(g) \\
\begin{array}{l}\text { Mean } \pm S E M \\
\text { (range })\end{array}\end{array}$} & \multirow{2}{*}{ 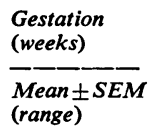 } & \multirow{2}{*}{$\frac{\text { Mortality }}{\text { No. }(\%)}$} \\
\hline & & & \\
\hline In study $(n=34)$ & $\begin{array}{l}949 \pm 29 \\
(570-1190)\end{array}$ & $\begin{array}{l}26 \pm 0.4 \\
(24-32)\end{array}$ & $7(20 \cdot 6)$ \\
\hline $\begin{array}{l}\text { Excluded from study } \\
(n=6) \\
\text { (deaths }<24 \text { hours) }\end{array}$ & $\begin{array}{l}973 \pm 73 \\
(730-1195)\end{array}$ & $\begin{array}{l}27 \pm 0 \cdot 6 \\
(25-29)\end{array}$ & 6 \\
\hline $\begin{array}{l}\text { Total }<1200 \mathrm{~g} \\
\quad(\mathrm{n}=40)\end{array}$ & $\begin{array}{l}953 \pm 26 \\
(570-1195)\end{array}$ & $\begin{array}{l}27 \pm 0 \cdot 3 \\
(24-32)\end{array}$ & $13(32 \cdot 5)$ \\
\hline
\end{tabular}

Seven of the 34 infants in the trial died (mortality rate $20.6 \%$ ), 5 during the 2-week trial period and 2 in the 3 rd week after birth.

The clinical data of the 17 infant pairs are summarised in Table 3. The groups were comparable in regard to birthweight and gestation. No infant had a birthweight under the 10th centile for gestational age. There were more boys, more infants with respiratory distress or apnoea, and more babies requiring oxygen or assisted ventilation in the TPN group compared with the Milk group. The differences were however, not significant. The mortality within the trial period in the TPN group ( 3 or $18 \%$ ) was not statistically different from that in the Milk group ( 2 or $12 \%$ ).

Four infants in the TPN group failed the trial. In one infant, the glucose amino-acid solution was not started within 3 days of birth because of severe metabolic acidosis from group B $\beta$-haemolytic streptococcal pneumonia. She subsequently recovered with treatment. The remaining 3 infants died during the course of the trial; 2 had intraventricular haemorrhages, one on day 3 and the other on day 5 , and one baby had a pulmonary haemorrhage on day 14. A further infant in the TPN group died after the trial, on day 21 , from an intraventricular haemorrhage.

Six infants in the Milk group failed the trial. One died on day 2 of an intraventricular haemorrhage and one died on day 14 as a result of necrotising enterocolitis. Three other infants developed necrotising enterocolitis on days 8,10 , and 12 , all of whom recovered with treatment. One infant had aspiration pneumonia on day 14. A further infant in the Milk group died after the trial on day 19 of an intraventricular haemorrhage. Trial failures in the two groups are summarised in Table 4.

Intake. Data on volume and energy intake are shown in Table 5 . The mean daily volume intake during the 1 st week was $152 \mathrm{ml} / \mathrm{kg}$ per 24 hours in

Table 3 Comparison of clinical data and mortality for infants in the TPN and Milk groups

\begin{tabular}{|c|c|c|}
\hline & $T P N(n=17)$ & Milk $(n=17)$ \\
\hline \multicolumn{3}{|l|}{ Birthweight (g) } \\
\hline $\begin{array}{l}\text { Mean } \pm \text { SEM } \\
\text { Range }\end{array}$ & $\begin{array}{l}922 \pm 39 \\
570-1180\end{array}$ & $\begin{array}{l}976 \pm 42 \\
660-1190\end{array}$ \\
\hline \multicolumn{3}{|l|}{ Gestation (weeks) } \\
\hline $\begin{array}{l}\text { Mean } \pm \text { SEM } \\
\text { Range }\end{array}$ & $\begin{array}{l}27 \pm 0 \cdot 5 \\
24-32\end{array}$ & $\begin{array}{l}28 \pm 0 \cdot 5 \\
24-32\end{array}$ \\
\hline Male to female ratio & $11: 6$ & $7: 10$ \\
\hline Respiratory distress & 13 & 11 \\
\hline Recurrent apnoea & 4 & 3 \\
\hline Oxygen therapy & 16 & 13 \\
\hline Assisted ventilation & 16 & 11 \\
\hline Deaths during trial & 3 & 2 \\
\hline Deaths after trial & 1 & 1 \\
\hline
\end{tabular}


Table 4 Trial failures in the TPN and Milk groups

\begin{tabular}{|c|c|c|c|c|c|}
\hline Case & $\begin{array}{l}\text { Birth- } \\
\text { weight } \\
(g)\end{array}$ & $\begin{array}{l}\text { Gestation } \\
\text { (weeks) }\end{array}$ & $\begin{array}{l}\text { Cause for trial } \\
\text { failure }\end{array}$ & $\begin{array}{l}\text { Day of } \\
\text { trial } \\
\text { failure }\end{array}$ & Outcome \\
\hline \multicolumn{6}{|l|}{$T P N$} \\
\hline 1 & 730 & 24 & $\begin{array}{l}\text { Pneumonia and } \\
\text { severe acidosis }\end{array}$ & 3 & Recovered \\
\hline 2 & 810 & 28 & $\begin{array}{c}\text { Intraventricular } \\
\text { haemorrhage }\end{array}$ & 4 & $\begin{array}{l}\text { Died on } \\
\text { day } 5\end{array}$ \\
\hline 3 & 920 & 25 & $\begin{array}{c}\text { Intraventricular } \\
\text { haemorrhage }\end{array}$ & 3 & $\begin{array}{c}\text { Died on } \\
\text { day } 3\end{array}$ \\
\hline 4 & 1040 & 29 & $\begin{array}{l}\text { Pulmonary } \\
\text { haemorrhage }\end{array}$ & 14 & $\begin{array}{l}\text { Died on } \\
\text { day } 14\end{array}$ \\
\hline \multicolumn{6}{|l|}{ Milk } \\
\hline 1 & 660 & 26 & $\begin{array}{c}\text { Intraventricular } \\
\text { haemorrhage }\end{array}$ & 2 & $\begin{array}{l}\text { Died on } \\
\text { day } 2\end{array}$ \\
\hline 2 & 880 & 27 & $\begin{array}{l}\text { Aspiration } \\
\text { pneumonia }\end{array}$ & 14 & Recovered \\
\hline 3 & 880 & 26 & $\begin{array}{l}\text { Necrotising } \\
\text { enterocolitis }\end{array}$ & 10 & Recovered \\
\hline 4 & 1090 & 27 & $\begin{array}{l}\text { Necrotising } \\
\text { enterocolitis }\end{array}$ & 8 & Recovered \\
\hline 5 & 1155 & 30 & $\begin{array}{l}\text { Necrotising } \\
\text { enterocolitis }\end{array}$ & 12 & Recovered \\
\hline 6 & 1190 & 28 & $\begin{array}{l}\text { Necrotising } \\
\text { enterocolitis }\end{array}$ & 13 & $\begin{array}{l}\text { Died on } \\
\text { day } 14\end{array}$ \\
\hline
\end{tabular}

Table 5 Comparison of volume and energy intakes during the 1st and 2nd weeks in the TPN and Milk groups

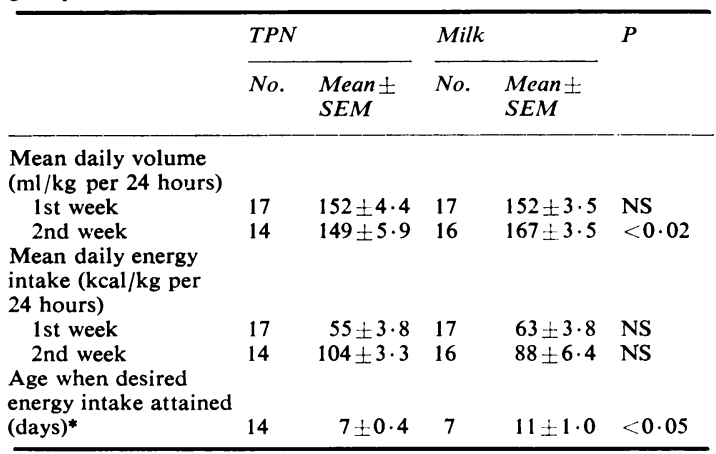

TPN, $90 \mathrm{kcal} / \mathrm{kg}$ per 24 hours; Milk, $120 \mathrm{kcal} / \mathrm{kg}$ per 24 hours (Cashore et al., 1975).

Conversion: traditional units to $\mathrm{SI}-1 \mathrm{kcal} \approx 4 \cdot 185 \mathrm{~kJ}$.

both groups. In the 2 nd week, infants in the Milk group required significantly higher daily mean volume intakes compared with those in the TPN group in order to maintain normal hydration and serum osmolality. Milk provided an average of $62 \%$ of the volume intake on day 7 and $83 \%$ by day 14 (Fig. 1). With the exception of 3 infants who were fed exclusively on Similac and one infant who died before starting milk feeds, the remaining 13 infants in the Milk group were given fresh expressed breast milk, even though this was often complemented with Similac when the supply of breast milk was interrupted.

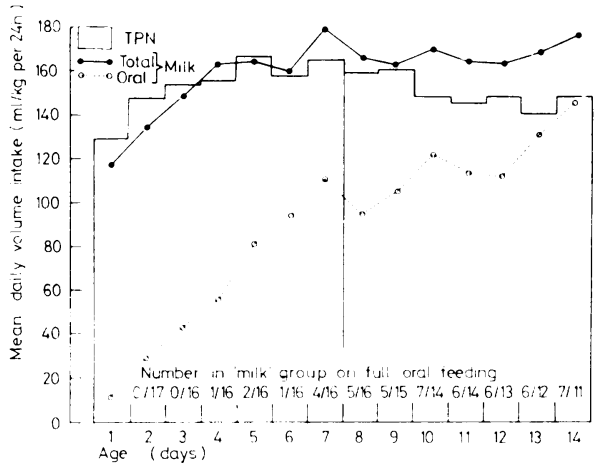

Fig. 1 Comparison of volume intake in the TPN and Milk groups.

The mean daily energy intake in the 1st and 2nd week was not significantly different in the two groups (Table 5). The number of infants and the ages at which they attained the desired energy intakes according to data of Cashore et al. (1975) were determined. 14 infants in the TPN group attained the parenteral desired energy of $90 \mathrm{kcal}(380 \mathrm{~kJ}) / \mathrm{kg}$ per 24 hours during the study period at an average age of 7 days compared with 7 infants in the Milk group who attained the oral desired energy intake of $120 \mathrm{kcal}(500 \mathrm{~kJ}) / \mathrm{kg}$ per 24 hours at an average age of 11 days. This difference was statistically significant. Milk provided an average of $78 \%$ of the energy intake on day 7 and $93 \%$ by day 14 (Fig. 2).

The mean daily carbohydrate, protein, and fat intakes in the two groups during the 1st and 2nd weeks are shown in Figs 3 and 4 . There was a significantly higher intake of carbohydrates and protein in both weeks in the TPN group compared with the Milk group. 14 infants in the TPN group attained the desired protein intake of $2.6 \mathrm{~g} / \mathrm{kg}$ per 24 hours during

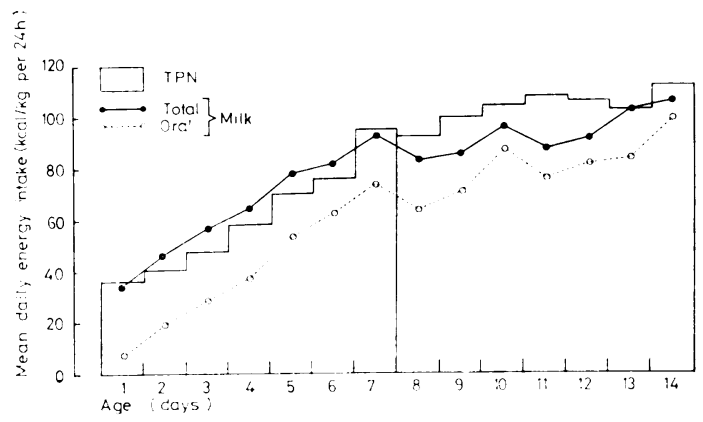

Fig. 2 Comparison of energy intake in the TPN and Milk groups. 


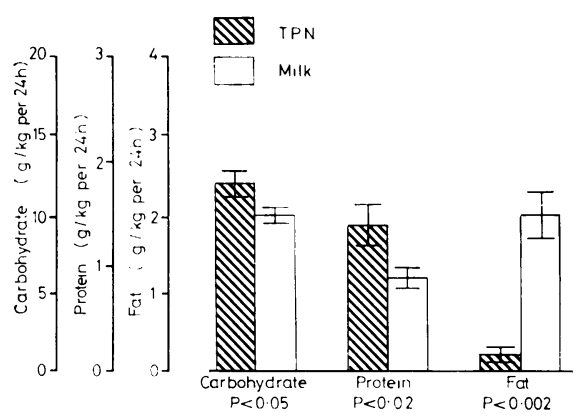

Fig. 3 Comparison of carbohydrate, protein, and fat intakes during the 1st week in the TPN and Milk groups. Data expressed as mean $\pm S E M$.

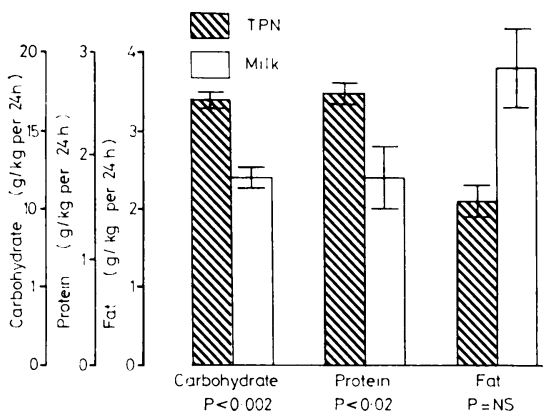

Fig. 4 Comparison of carbohydrate, protein, and fat intakes during the 2nd week in the TPN and Milk groups. Data expressed as mean $\pm S E M$.

the study period compared with 9 infants in the Milk group. Mean daily fat intake during the 1st week was significantly lower in the TPN group compared with the Milk group. With infants in the TPN group, Intralipid was started only after recovery from neonatal jaundice at a mean of 7 days with a range of 5 to 11 days. No significant difference was observed in the mean daily fat intake in the 2 nd week.

Weight changes. Table 6 and Fig. 5 show the weight changes for the two groups. There was no statistical difference in the mean daily weight loss in the 1st week and the maximum postnatal weight loss in the two groups. Infants in the TPN group began to gain weight sooner and faster compared with those in the Milk group, as shown by a significantly earlier age at lowest weight, a greater mean daily weight gain in the 2 nd week, and a shorter mean time to regain and maintain birthweight. There was no statistical difference between the two groups in the age at which the infants attained $2000 \mathrm{~g}$ or the time of discharge
Table 6 Comparison of postnatal weight changes of infants in the TPN and Milk groups

\begin{tabular}{|c|c|c|c|c|c|}
\hline & \multicolumn{2}{|c|}{$T P N$} & \multicolumn{2}{|c|}{ Milk } & \multirow[t]{2}{*}{$P$} \\
\hline & No. & $\begin{array}{l}\text { Mean士 } \\
\text { SEM }\end{array}$ & No. & $\begin{array}{l}\text { Mean } \\
\text { SEM }\end{array}$ & \\
\hline $\begin{array}{l}\text { Mean daily weight loss } \\
\text { in } 1 \text { st week (g/day) }\end{array}$ & 17 & $8 \pm 2 \cdot 2$ & 17 & $12 \pm 1 \cdot 8$ & NS \\
\hline $\begin{array}{l}\text { Postnatal weight loss } \\
\text { (\% of birthweight) }\end{array}$ & 17 & $11 \pm 1 \cdot 4$ & 17 & $12 \pm 1 \cdot 7$ & NS \\
\hline $\begin{array}{l}\text { Age at lowest weight } \\
\text { (days) } \\
\text { Mean daily weight gain }\end{array}$ & 14 & $5 \pm 0 \cdot 3$ & 16 & $7 \pm 0 \cdot 6$ & $<0.02$ \\
\hline $\begin{array}{l}\text { in } 2 \text { nd week (g/day) } \\
\text { Time to regain and }\end{array}$ & 14 & $15 \pm 2 \cdot 6$ & 16 & $7 \pm 2 \cdot 4$ & $<0.02$ \\
\hline (days) & 14 & $12 \pm 1 \cdot 2$ & 11 & $17 \pm 1 \cdot 5$ & $<0.05$ \\
\hline
\end{tabular}
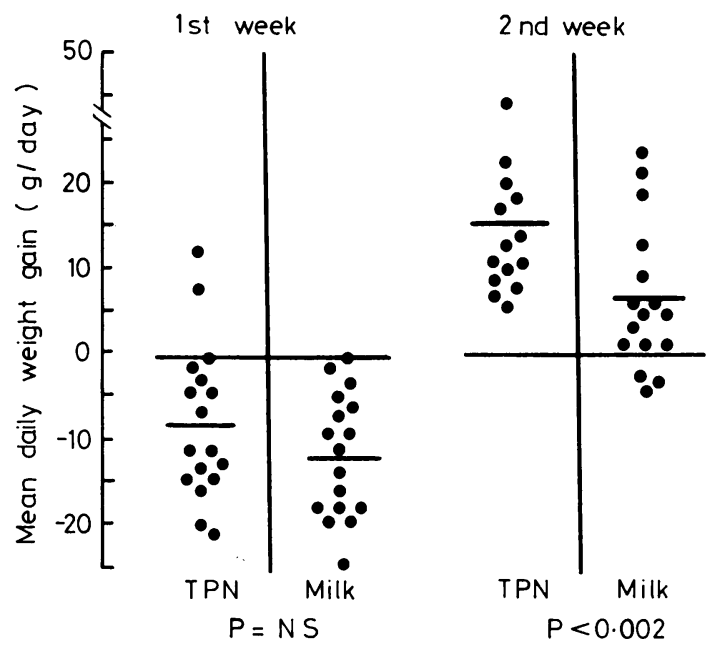

Fig. 5 Comparison of postnatal weight changes for infants in the TPN and Milk groups. Horizontal bar shows mean values for each group.

from hospital. However, 3 of the 10 infants in the Milk group whose oral intake was still under $100 \mathrm{kcal} / \mathrm{kg}$ at the end of the 2-week trial were offered parenteral nutrition supplements, and 5 of the 27 survivors were transferred to the referring hospital for convalescent care before discharge. Such comparisons beyond the trial period are therefore difficult to interpret.

Complications. Metabolic disturbances are summarised in Table 7. Serum hyperosmolality was detected in 4 infants in the TPN group and in 2 in the Milk group. None of these infants developed intracranial haemorrhage. Hyperglycaemia was observed in both groups. All responded promptly to appropriate adjustments in the glucose infusion rate and insulin was not required. Electrolyte 
Table 7 Comparison of number of infants with metabolic disturbances during the study period in the TPN and Milk groups

\begin{tabular}{|c|c|c|c|}
\hline Serum values & & $T P N$ & Milk \\
\hline Osmolality (mmol/kg) & $\begin{array}{l}>320 \\
<260\end{array}$ & $\begin{array}{l}4 \\
2\end{array}$ & $\begin{array}{l}2 \\
4\end{array}$ \\
\hline Glucose (mmol/1) & $\begin{array}{l}>11 \\
<1.5\end{array}$ & $\begin{array}{l}9 \\
0\end{array}$ & $\begin{array}{l}6 \\
1\end{array}$ \\
\hline Sodium (mmol/l) & $\begin{array}{l}>150 \\
<120\end{array}$ & $\begin{array}{l}1 \\
2\end{array}$ & $\begin{array}{l}2 \\
2\end{array}$ \\
\hline Potassium (mmol/1) & $\begin{array}{l}>8 \\
<3\end{array}$ & $\begin{array}{l}1 \\
2\end{array}$ & $\begin{array}{l}1 \\
2\end{array}$ \\
\hline Calcium (mmol/l) & $\begin{array}{l}>2.5 \\
<1.7\end{array}$ & $\begin{array}{l}5 \\
7\end{array}$ & $\begin{array}{l}4 \\
8\end{array}$ \\
\hline Magnesium (mmol/1) & $\begin{array}{l}>1 \cdot 2 \\
<0 \cdot 7\end{array}$ & $\begin{array}{l}1 \\
2\end{array}$ & $\begin{array}{l}0 \\
6\end{array}$ \\
\hline 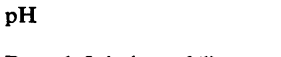 & $\begin{array}{l}<27 \cdot 5 \\
>7 \cdot 50\end{array}$ & $\begin{array}{l}6 \\
2\end{array}$ & $\begin{array}{l}9 \\
2\end{array}$ \\
\hline $\begin{array}{l}\text { Base deficit }(\mathrm{mmol} / \mathrm{l}) \\
\text { Lactate }(\mathrm{mmol} / \mathrm{l})\end{array}$ & $\begin{array}{l}>10 \\
>2\end{array}$ & $\begin{array}{l}3 \\
2\end{array}$ & $\begin{array}{l}3 \\
0\end{array}$ \\
\hline Bilirubin $(\mu \mathrm{mol} / \mathrm{l})$ & $>200$ & 9 & 6 \\
\hline $\operatorname{AST}(\mu / 1)$ & $>55$ & 3 & 0 \\
\hline Alkaline phosphatase $(\mu / 1)$ & $>800$ & 2 & 3 \\
\hline Proteins $(\mathrm{g} / \mathrm{l})$ & $<40$ & 3 & 5 \\
\hline Urea (mmol/l) & $>8$ & 1 & 0 \\
\hline Ammonia $(\mu \mathrm{g} / 100 \mathrm{ml})$ & $>150$ & 0 & 1 \\
\hline
\end{tabular}

Conversion: SI to traditional units-glucose: $1 \mathrm{mmol} / 1 \approx 18 \mathrm{mg} / 100$ $\mathrm{ml}$; calcium: $1 \mathrm{mmol} / 1 \approx 4 \mathrm{mg} / 100 \mathrm{ml}$; magnesium: $1 \mathrm{mmol} / 1 \approx$ $2.4 \mathrm{mg} / 100 \mathrm{ml}$; lactate: $1 \mathrm{mmol} / 1 \approx 9 \mathrm{mg} / 100 \mathrm{ml}$; bilirubin: $1 \mu \mathrm{mol} / \mathrm{l}$ $\approx 0.06 \mathrm{mg} / 100 \mathrm{ml}$; urea: $1 \mathrm{mmol} / 1 \approx 6 \mathrm{mg} / 100 \mathrm{ml}$.

disturbances were comparable in both groups and were corrected as they appeared. TPN did not contribute significantly to the severity of metabolic acidosis compared with the conventional feeding method. Most infants in both groups developed hyperbilirubinaemia $>150 \mathrm{mmol} / 1$ and required phototherapy. An increase in conjugated bilirubin was observed in 3 infants in the TPN group who also had raised AST levels at the end of TPN. One had cholestatic jaundice associated with postnatally acquired cytomegalovirus infection. There was a transient increase in the level of blood urea in one infant in the TPN group, and one infant in the milk group had one reading of a high blood ammonia level.

Bacterial or fungal septicaemia was not a complication in infants in either group during the study period. One infant in the TPN group who continued to require TPN for 10 weeks subsequently developed candida septicaemia but recovered on systemic amphotericin B.

\section{Discussion}

Results are given of a controlled study of 34 critically ill low birthweight infants, half of whom received intragastric milk feeding and, as necessary, IV glucose and electrolyte supplements. The other half received total parenteral nutrition. As the conventional practice is to establish an intra-arterial infusion on admission, infants in the Milk group all had IV glucose which supplemented the fluid and energy intakes during the period in which the volume of milk feeds was increased. It is therefore not possible to obtain a 'pure' milk feed group in infants under $1200 \mathrm{~g}$. However it was considered that a true assessment of the advantages of parenteral nutrition for such infants could be gained only if the latter replaced milk feeding rather than supplemented it. Interpretation of previous reports of total parenteral nutrition is difficult in the absence of adequate controls fed conventionally under identical medical supervision. Studies have been biased by excluding infants with respiratory distress or those who required assisted ventilation (Driscoll et al., 1972; Bryan et al., 1973). Yet, these are the very infants who would particularly benefit from more calories and who are most difficult to feed orally. In the present study, infants were randomly assigned to a feeding method and none was excluded after starting the designated regimen.

Dweck and Cassady (1974) reported that hyperglycaemia was observed in $86 \%$ of very low birthweight infants receiving parenteral glucose. This was reported to be related to high glucose infusion rates exceeding $9.6 \mathrm{~g} / \mathrm{kg}$ per 24 hours. Accordingly, the TPN regimen was designed to begin with a glucose load of $8 \mathrm{~g} / \mathrm{kg}$ per 24 hours on day 1 . It was possible, however, progressively to increase the mean glucose infusion rate within tolerance limits to $18 \mathrm{~g} / \mathrm{kg}$ per 24 hours by 7 days after birth. The incidence of hyperglycaemia in the TPN group was similar to that in the Milk group. This complication was resolved by lowering the glucose infusion rate.

Formulated crystalline amino-acid mixtures are more effective than protein hydrolysates as the latter contain considerable amounts of small peptides that are not efficiently used. Of the crystalline amino-acid solutions, Vamin contains only $\mathrm{L}$ amino-acid isomers and is more efficiently used with respect to nitrogen metabolism than that containing both the $\mathrm{D}$ and $\mathrm{L}$ isomers, as in the case of Aminofusin (Pfimmer, Erlangen, West Germany), because of lower urinary amino-acid losses (Hendry et al., 1978). Furthermore, Vamin maintains serum amino-acid concentrations that are close to normal in small premature infants (Shaw et al., 1977), whereas Aminofusin seriously disrupts normal amino-acid concentrations (Kellerman et al., 1976). The recommended dose of $3 \mathrm{~g}$ of amino-acids (equivalent approximately to $2.6 \mathrm{~g}$ protein)/kg per 24 hours given in this study, using Vamin as the nitrogen source, is based on work previously carried out here (Kellerman et al., 1976; Shaw et al., 1977; Hendry et al., 1978). Heird et al. (1972a) suggested that the metabolism of excessive cationic amino-acids results in excess of hydrogen 
ion which leads to metabolic acidosis during parenteral nutrition. The incidence of this complication was low and similar in the TPN and Milk groups. It is possible that the acetate in the TPN solution acts as a bicarbonate precursor and is capable of buffering the excess hydrogen ion formed. Hyperammonaemia observed in infants given parenteral nutrition has been attributed to high ammonia content in protein hydrolysates or to inadequate arginine in the crystalline amino-acid solution (Heird et al., 1972c; Johnson et al., 1972). This complication was not observed in this study.

Less mature infants had a poorer Intralipid tolerance initially, as was observed by Shennan $e t$ al. (1977). However, most infants tolerated $3 \mathrm{~g} / \mathrm{kg}$ fat per 24 hours by the 2 nd week as had been shown previously (Cashore et al., 1975; Gunn et al., 1978). It has been noted, however, that some infants on Intralipid can develop high plasma levels of free fatty acids which can interfere with bilirubinalbumin binding and thus increase the risk of bilirubin encephalopathy (Andrew et al., 1976). As we had no method for monitoring the effects of free fatty acids on bilirubin-albumin binding, it was decided that an increasing serum bilirubin level, or one $>150 \mu \mathrm{mol} / \mathrm{l}$, is a contraindication for Intralipid. This was found to occur in all the infants in this series within the first 5 days, thus contributing to the insufficient energy intake in the TPN group during this early period. Adequate monitoring of the Intralipid-bilirubin relationship by determining the reserve bilirubin-binding capacity or by calculating the free fatty acids to albumin molar ratio will provide a safety index for Intralipid use in the presence of neonatal jaundice.

The introduction of neonatal intensive care has led to a decrease in the mortality rate of very low birthweight infants (Stewart et al., 1977). At the Queen Victoria Medical Centre, infants weighing $<1000 \mathrm{~g}$ had over $80 \%$ mortality in the 3 years 1970 to 1972 (MacMahon et al., 1975), whereas the mortality rates for those weighing 501 to $1000 \mathrm{~g}$ and 1001 to $1500 \mathrm{~g}$ were 52 and $20 \%$ respectively during 1977 (Yu and Wood, 1978). The reason for this improvement in outlook is obviously multifactorial, of which early adequate nutrition provided by safer methods is only one factor. An effect upon mortality can only be formally demonstrated by a carefully controlled study. However, it is impossible to isolate this one factor in the very low birthweight infant in whom the mortality will, in any case, be high. As in the one previous report of TPN versus a control group managed with the conventional feeding regimen (Gunn et al., 1978), no statistically significant differences in mortality rate between the two groups could be shown. One factor which is not comparably matched in the two groups is the sex of the infants. The fact that there were 10 girls in the Milk group compared with 6 in the TPN group suggests that the Milk group was more favourably placed, allowing for the expected male preponderance in mortality.

Infants in the TPN group had earlier and greater weight gain than those in the Milk group, despite similar total caloric intake. Oral nutrients are poorly absorbed in preterm infants. The energy need in achieving weight gain observed in the present study is in agreement with that by Cashore et al. (1975) who reported that most infants gained weight at the expected rate of fetal growth in utero $(20 \mathrm{~g}$ per day at 28 weeks and $30 \mathrm{~g}$ per day at 34 weeks) when the desired energy intake of $90 \mathrm{kcal}(380 \mathrm{~kJ}) / \mathrm{kg}$ per 24 hours of parenteral nutrition or $120 \mathrm{kcal}(500 \mathrm{~kJ}) / \mathrm{kg}$ per 24 hours of milk feeding was attained. Furthermore, the nitrogen intake of the Milk group was significantly lower than that of the TPN group for the duration of the study. In the 2nd week, the TPN group achieved the recommended parenteral nitrogen requirement of Vamin-fed preterm infants (Hendry et al., 1978) of $30 \mathrm{mmol} / \mathrm{kg}$ nitrogen per 24 hours, equivalent to $3.1 \mathrm{~g}$ of amino-acids or $2.6 \mathrm{~g} / \mathrm{kg}$ protein per 24 hours. The latter study also showed that only $80 \%$ of the oral nitrogen intake in these Similac-fed infants was absorbed, which put the infants in the Milk group at a further disadvantage. It has nevertheless been suggested that the faster weight gain observed in parenterally supplemented infants compared with their orally-fed controls might be attributable to water retention rather than to more rapid tissue accretion (Brans et al., 1976); but in that study, there was no difference in daily protein intake between the two groups. Firm conclusions must await further studies, including concomitant estimates of total and extracellular body water.

Comparison of the morbidity in the two groups showed that no baby in the TPN group had necrotising enterocolitis whereas 4 infants in the Milk group developed this during the first 2 weeks, one of whom died despite surgical intervention for intestinal perforation. Enteric feeding, particularly for babies with mucosal ischaemia, was thought to be of aetiological significance in the development of necrotising enterocolitis (Yu and Tudehope, 1977). This has to be considered as a significant morbidity associated with milk feeding in very low birthweight infants in addition to the more commonly described aspiration pneumonia for which there was also one example in the Milk group in the present study. The incidence of intraventricular haemorrhage was similar in the two groups. None of the 5 infants with this complication had serum hyperosmolality but 4 of them, 2 in each group, had blood glucose 
levels $>11 \mathrm{mmol} / \mathrm{l}$. A further 11 infants were found to have transient hyperglycaemia but did not develop intraventricular haemorrhage. Though TPN in this study has not been shown to increase the incidence of hyperosmolality or hyperglycaemia compared with milk feeding, the clinical implication of hyperglycaemia in intraventricular haemorrhage (Dweck and Cassady, 1974) needs further study.

Metabolic complications were relatively common, but in no case were these persistent or considered to have resulted in serious consequences. The number of recorded disturbances could be attributed to the fact that the infants were closely monitored. Constant laboratory support, using microtechniques, was needed for early diagnosis so that rapid adjustments in the composition of the infusate could be made. However, it is reasonably certain that if monitoring had been less thorough or if a 'standard' mixture had been used, serious and perhaps fatal metabolic complications could have ensued.

This controlled study has shown a more adequate nitrogen intake and an improved weight gain, an avoidance of necrotising enterocolitis, but an unchanged mortality rate in very low birthweight infants managed with TPN compared with conventional milk feeding during the first 2 weeks after birth. Complications which could be specifically assigned to TPN were few. The possibility that TPN may be responsible for intrahepatic cholestasis in some very low birthweight infants is being investigated. Long-term studies of neurological, intellectual, and behavioural development are needed and are currently in progress.

We thank Dr M. Adamson, Dr P. Das, Dr B. Jack, and Dr T. Lambert, consultants in the Neonatal Intensive Care Unit, Miss E. Hollingsworth (charge sister) and her nursing staff, Mr R. Arulappu (Director of Pharmaceutical Services) and his staff, and the Biochemistry Department of the Medical Centre for their co-operation in the study.

This project was supported in part by $\mathrm{NH}$ and MRC grant number $69 / 5038$.

\section{References}

Abitbol, C. L., Feldman, D. B., Ahmann, P., and Rudman, D. (1975). Plasma aminoacid patterns during supplemental intravenous nutrition of low-birthweight infants. Journal of Pediatrics, 86, 766-772.

Andrew, G., Chan, G., and Schiff, D. (1976). Lipid metabolism in the neonate. II. The effect of Intralipid on bilirubin binding in vitro and in vivo. Journal of Pediatrics, 88, 279-284.

Benda, G. I. M., and Babson, S. G. (1971). Peripheral intravenous alimentation of the small premature infant. Journal of Pediatrics, 79, 494-498.
Brans, Y. W., Sumners, J. E., Dweck, H. S., and Cassady, G. (1974). Feeding the low birthweight infant: orally or parenterally? I. Preliminary results of a comparative study. Pediatrics, 54, 15-22.

Brans, Y. W., Sumners, J. E., Dwesk, H. S., Bailey, P. E., and Cassady, G. (1976). Feeding the low birthweight infant: orally or parenterally? II. Corrected bromide space in parenteral supplemented infants. Pediatrics, 58, 809-815.

Bryan, M. H., Wei, P., Hamilton, J. R., Chance, G. W., and Swyer, P. R. (1973). Supplemental intravenous alimentation in low-birthweight infants. Journal of Pediatrics, 82, 940-944.

Cashore, W. J., Sedaghatian, M. R., and Usher, R. H. (1975). Nutritional supplements with intravenously administered lipid, protein hydrolysate, and glucose in small premature infants. Pediatrics, 56, 8-16.

Dobbing, J. (1974). The later growth of the brain and its vulnerability. Pediatrics, 53, 2-6.

Driscoll, J. M., Jr, Heird, W. C., Schullinger, J. N., Gongaware, R. D., and Winters, R. W. (1972). Total intravenous alimentation in low-birthweight infants: a preliminary report. Journal of Pediatrics, 81, 145-153.

Dweck, H. S., and Cassady, G. (1974). Glucose intolerance in infants of very low birthweight. I. Incidence of hyperglycemia in infants of birthweights 1100 grams or less. Pediatrics, 53, 189-195.

Gunn, T., Reaman, G., Outerbridge, E. W., and Colle, E. (1978). Peripheral total parenteral nutrition for premature infants with the respiratory distress syndrome: a controlled study. Journal of Pediatrics, 92, 608-613.

Hall, R. T., and Rhodes, P. G. (1976). Total parenteral alimentation via indwelling umbilical catheters in the newborn period. Archives of Disease in Childhood, 51, 929-934.

Heird, W. C., Dell, R. B., Driscoll, J. M., Grebin, B., and Winters, R. W. (1972a). Metabolic acidosis resulting from intravenous alimentation mixtures containing synthetic amino acids. New England Journal of Medicine, 287, 943-948.

Heird, W. C., Driscoll, J. M., Jr, Schullinger, J. N., Grebin, B., and Winters, R. W. (1972b). Intravenous alimentation in pediatric patients. Journal of Pediatrics, 80, 351-372.

Heird, W. C., Nicholson, J. F., Driscoll, J. M., Jr, Schullinger, J. N., and Winters, R. W. (1972c). Hyperammonemia resulting from intravenous alimentation using a mixture of synthetic L-amino acids: a preliminary report. Journal of Pediatrics, 81, 162-165.

Hendry, P. G., James, B. E., and MacMahon, R. A. (1978). Nitrogen balance studies during oral and complete intravenous feeding of small premature infants. Australian Paediatric Journal, 14, 6-10.

Johnson, J. M., Albritton, W. L., and Sunshine, P. (1972). Hyperammonemia accompanying parenteral nutrition in newborn infants. Journal of Pediatrics, 81, 154-161.

Kellerman, G. M., MacMahon, R. A., Leber, M. A., and James, B. E. (1976). Amino-acid studies during complete intravenous feeding of small premature infants. Australian Paediatric ,ournal, 12, 255-260.

MacMahon, R. A., James, B. E., and Nam, D. (1975). Preliminary results of a clinical trial of intravenous feeding in premature infants of birthweight $1050 \mathrm{~g}$ or less. Australian Paediatric Journal, 11, 154-159.

Meng, H. C., Stahlman, M. T., Otten, A., Dolanski, E. A., Caldwell, M. D., and O'Neill, J. A. (1977). The use of a crystalline amino acid mixture for parenteral nutrition in low-birthweight infants. Pediatrics, 59, 699-709.

Peden, V. H., and Karpel, J. T. (1972). Total parenteral nutrition in premature infants. Journal of Pediatrics, 81, 137-144. 
Pildes, R. S., Ramamurthy, R. S., Cordero, G. V., and Wong, P. W. K. (1973). Intravenous supplementation of L-amino acids and dextrose in low-birthweight infants. Journal of Pediatrics, 82, 945-950.

Shaw, P. L. G., Kellerman, G. M., MacMahon, R. A., and James, B. E. (1977). Studies of aminoacid metabolism in small premature infants fed intravenously on Vaminbased solutions and orally on milk. Australian Paediatric Journal, 13, 148-149.

Shennan, A. T., Bryan, M. H., and Angel, A. (1977). The effect of gestational age on Intralipid tolerance in newborn infants. Journal of Pediatrics, 91, 134-137.

Stewart, A. L., Turcan, D. M., Rawlings, G., and Reynolds, E. O. R. (1977). Prognosis for infants weighing $1000 \mathrm{~g}$ or less at birth. Archives of Disease in Childhood, 52, 97-104.

Wharton, B. A., and Bower, B. D. (1965). Immediate or later feeding for premature babies? A controlled trial. Lancet, 2, 969-972.
Yu, V. Y. H. (1976). Cardiorespiratory response to feeding in newborn infants. Archives of Disease in Childhood, 51, 305-309.

Yu, V. Y. H., and Tudehope, D. I. (1977). Neonatal necrotising enterocolitis. II. Perinatal risk factors. Medical Journal of Australia, 1, 688-693.

Yu, V. Y. H., Tudehope, D. I., and Gill, G. (1977). Neonatal necrotising enterocolitis. I. Clinical aspects. Medical Journal of Australia, 1, 685-688.

Yu, V. Y. H., and Wood, C. (1978). Perinatal asphyxia and outcome of very low birthweight infants. Medical Journal of Australia, 2, 578-581.

Correspondence to Dr V. Y. H. Yu, Department of Paediatrics, Queen Victoria Medical Centre, Melbourne 3000, Australia.

Received 19 December 1978 